\title{
A review of geological and geotechnical features of some Middle Eastern countries
}

\author{
Harry G. Poulos ${ }^{1}$
}

Received: 30 April 2018 / Accepted: 5 May 2018 / Published online: 30 May 2018

(c) The Author(s) 2018

\begin{abstract}
This paper presents a collection of some of the available published information on geological and geotechnical characteristics of some Middle Eastern countries within the Arabian Peninsula. For each of the countries considered, a brief summary is given of the geological history, typical geotechnical profiles and typical geotechnical parameters, and if available, information on foundation design parameters. Such information may be helpful for preliminary design purposes, prior to a more detailed program of ground investigation being undertaken.
\end{abstract}

Keywords Arabian Peninsula $\cdot$ Deep foundations $\cdot$ Geology $\cdot$ Geotechnical parameters $\cdot$ Settlement $\cdot$ Shallow foundations

\section{Introduction}

This paper presents some of the available published information on geological and geotechnical characteristics of some Middle Eastern countries within the Arabian Peninsula (Fig. 1). Evans [10] has provided a summary of the geology and the soil conditions for a number of countries in the Middle East, and some of the information below is taken from this source, although more recent published information is now available on some areas, particularly Kuwait and Saudi Arabia. The major elements of the structural geology of the Arabian Peninsula are the Arabian Shield, and the Arabian Shelf, and these, together with the interior platform, and the basins, are summarized by Kent [23] and reproduced in Fig. 2. Kent [23] has given a broad overview of the geology of the Middle East and has identified some typical geological profiles that are reproduced in Fig. 3.

In this paper, for each of the countries considered, a brief summary will be given of the geological history, typical geotechnical profiles and typical geotechnical parameters, and if available, information on foundation design parameters.

Harry G. Poulos

harry.poulos@coffey.com

1 Coffey Services Australia, Sydney, Australia

\section{Dubai}

\section{Geology}

The geology of the United Arab Emirates (UAE), and the Arabian Gulf Area, has been substantially influenced by the deposition of marine sediments associated with numerous sea level changes during relatively recent geological time. With the exception of mountainous regions shared with Oman in the north-east, the country is relatively low-lying, with near-surface geology dominated by deposits of Quaternary to late Pleistocene age, including mobile aeolian dune sands, sabkha/evaporite deposits and marine sands. Dubai is situated towards the eastern extremity of the geologically stable Arabian Plate and is separated from the unstable Iranian Fold Belt to the north by the Arabian Gulf. It is believed that a tilting of the entire Arabian Plate occurred during the early Permian period, resulting in uplift in southern Yemen and depression to the north-east. Tectonic movements peripheral to folding of the Iranian Zagros Range during the Plio-Pleistocene epoch probably contributed to the formation of both the Arabian Gulf depression and the mountainous regions in the north-east of the UAE and Oman.

\section{Main stratigraphic units}

The main stratigraphic units encountered in Dubai are described briefly below, and a typical geotechnical profile is illustrated in Fig. 4. 


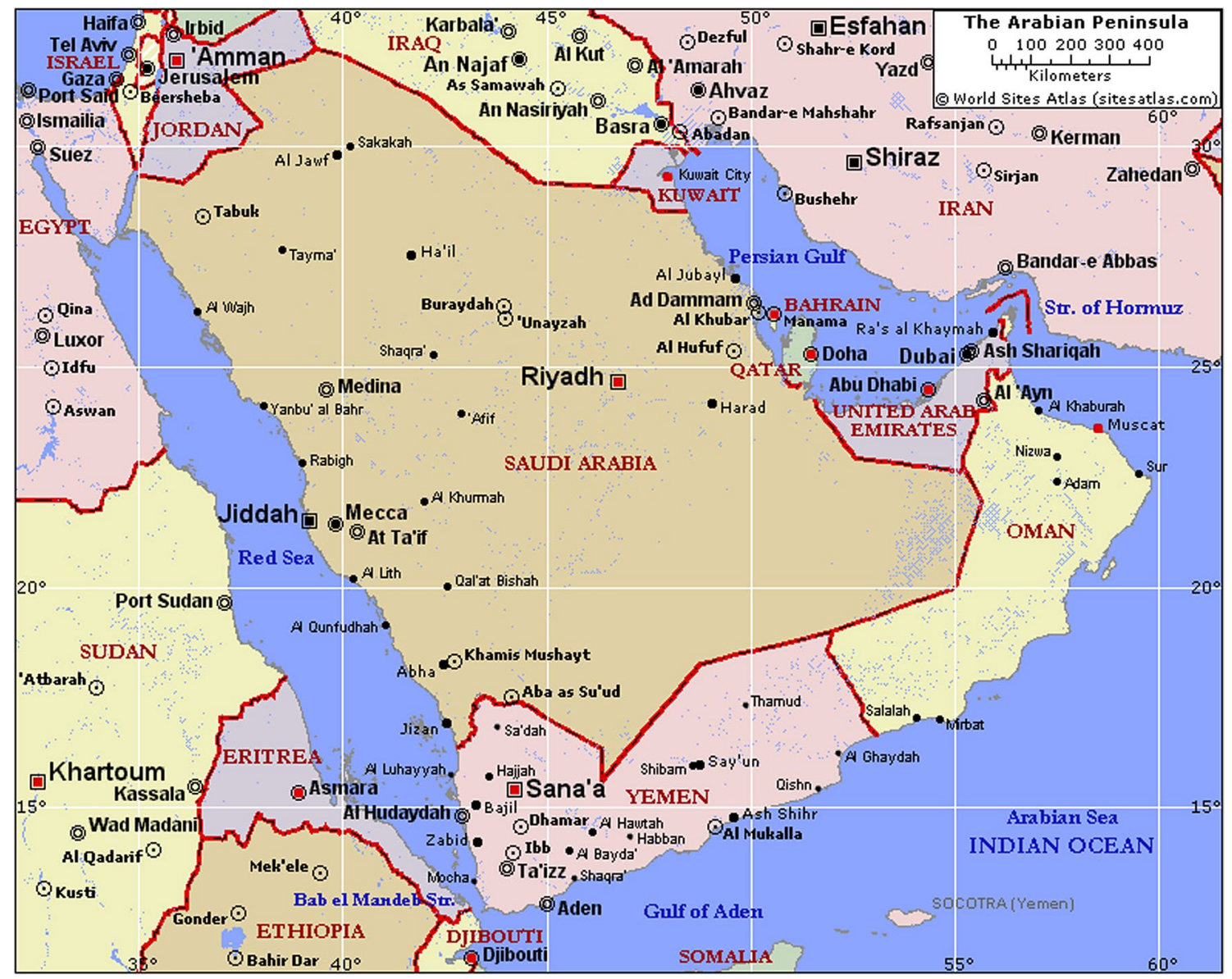

Fig. 1 Arabian Peninsula

Marine deposits The Marine Deposits generally occur in two or three layers of medium dense and very loose to loose brown grey silty to very silty sand, with occasional cemented lumps and shell fragments.

Calcarenite/calcareous sandstone This stratum typically comprises weak to moderately weak fine grained Calcarenite, interbedded withlcemented sand and with frequent shell fragments. The Calcarenite is generally underlain by very weak to weak, thinly to thickly laminated, grey brown, fine grained calcareous Sandstone.

Calcareous sandstone/calcarenite/sandstone/sand The stratum typically comprises very weak to weak, fine grained Calcarenite/calcareous Sandstone/Sandstone, interbedded with cemented sand. Bands of $<1 \mathrm{~m}$ up to approximately $5 \mathrm{~m}$ of medium dense to very dense, cemented sand with sandstone bands may occur within this stratum.

Gypsiferous sandstone/sand This stratum typically comprises very weak to weak, fine-grained gypsiferous sandstone interbedded with cemented sand.

Calcisiltite/conglomeritic calcisiltite This formation typically comprises very weak to weak calcisiltite (occasionally conglomeritic) and is encountered at levels ranging between -28 and $-72 \mathrm{~m}$ DMD.

Calcareous/conglomeritic stratum This unit typically comprises very weak to weak calcareous siltstone/calcareous conglomerate/conglomeritic sandstone/limestone.

Claystone/siltstone strata This stratum comprises very weak to moderately weak grey slaystone interbedded with reddish brown siltstone, between levels of about -110 and $-130 \mathrm{~m}$ DMD occasional thin bands of up to thick gypsum may be encountered. Below approximately -130 m DMD the stratum may be encountered as weak to moderately weak siltstone with medium to widely spaced fractures.

The groundwater table is typically $1-3 \mathrm{~m}$ below ground surface.

\section{Foundation design parameters}

Alrifai [8] presents some data on unconfined compressive strength (UCS) for relatively shallow strata, and the UCS values are low, generally between 1 and $3 \mathrm{MPa}$, with a considerable scatter in the data. 
Fig. 2 Summary of structural geology of the Arabian Peninsula [10]

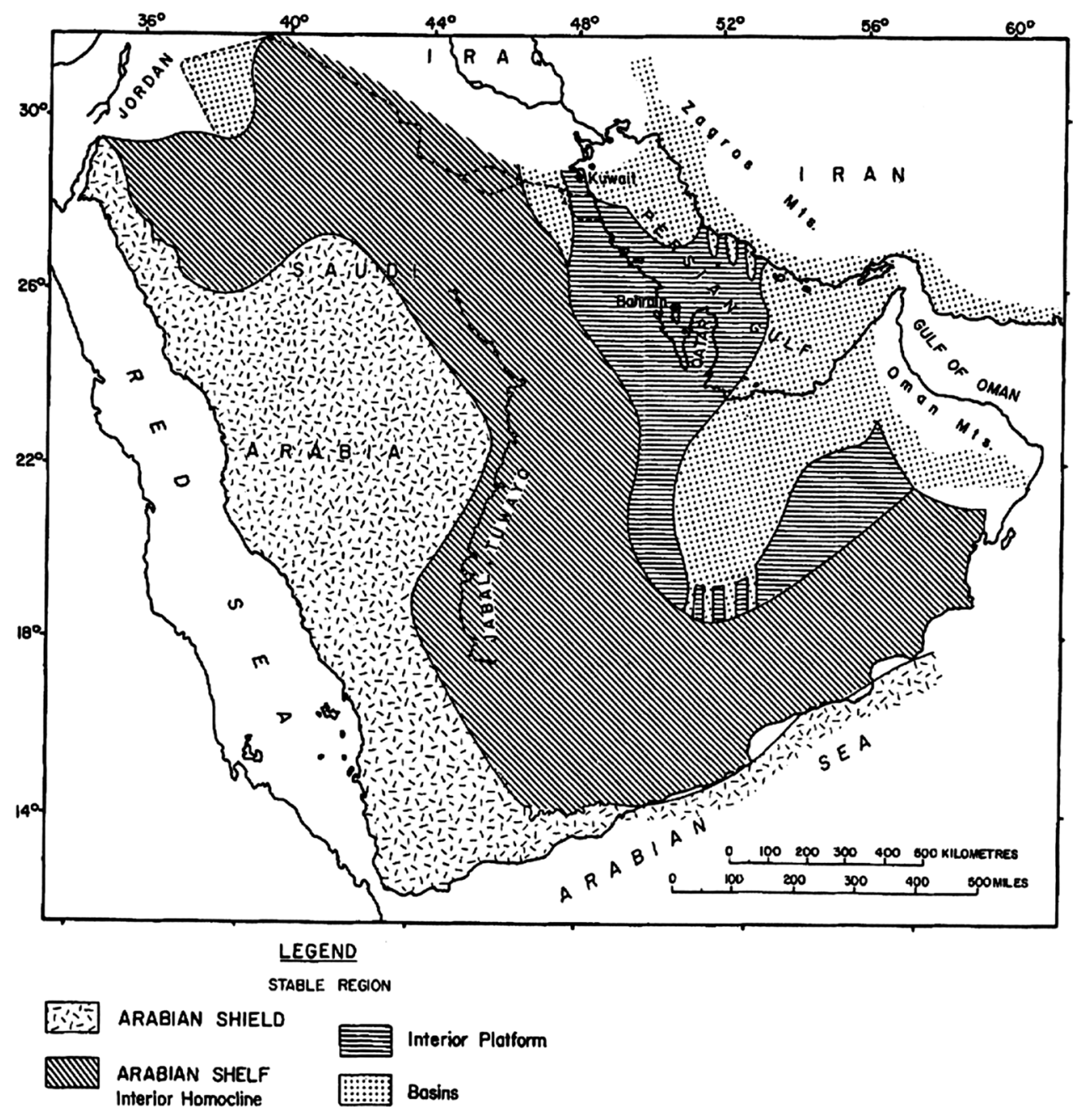

There is relatively little published information on foundation design parameters for buildings in Dubai. Poulos and Davids [28] have presented some information on pile design parameters employed for the design of the Emirates Towers. Alrifai [8] presents some data from a series of five load tests on bored piles with diameters ranging between 0.6 and $1.0 \mathrm{~m}$, and length between about 12 and $18 \mathrm{~m}$. There were 4 tests in compression and one in tension, and on the basis of these tests, Alrifai offered the following recommendations:

1. For design purposes, the ultimate skin friction values in Table 1 can be used for compression piles.

2. The ultimate skin friction for piles in tension is about 0.73 times that for compression.

3. For lateral loading, Young's modulus $E_{\mathrm{sh}}$ of the upper strata can be estimated from the following empirical correlation: $E_{\mathrm{sh}}=2.5 \mathrm{~N} \mathrm{MPa}$, where $N=\mathrm{SPT}-N$ value.

4. Only a small amount of load is transferred to the pile base, and it was recommended that end bearing be ignored for design.

\section{Kuwait}

\section{Geology}

Kuwait is part of the north-eastern Arabian Peninsula which rises gradually from the shores of the Arabian Gulf with gentle undulations towards the mountainous regions of the western Najd and the Hijaz. The mainland slopes generally towards the sea at an average gradient of 1 in 500, the highest elevation being $270 \mathrm{~m}$ in the south-west corner. In the north, an extensive plain is strewn with a thin layer of gravel, while the south-eastern quarter is low lying, flat and sandy. Behind the Az Zawr escarpment, there is a highly calcareous crust on the ground surface, creating hard areas devoid of sand.

The upper sedimentary rocks of Kuwait were deposited in shallow seas or were laid by streams, with the position of the shoreline changing frequently. Underneath the recent deposits, rocks ranging from Miocene to Pleistocene occur to a maximum thickness of 1000 m. In north Kuwait, beneath the recent superficial deposits, lies the Dibdibba 
Fig. 3 Some typical Middle East geological profiles [23]

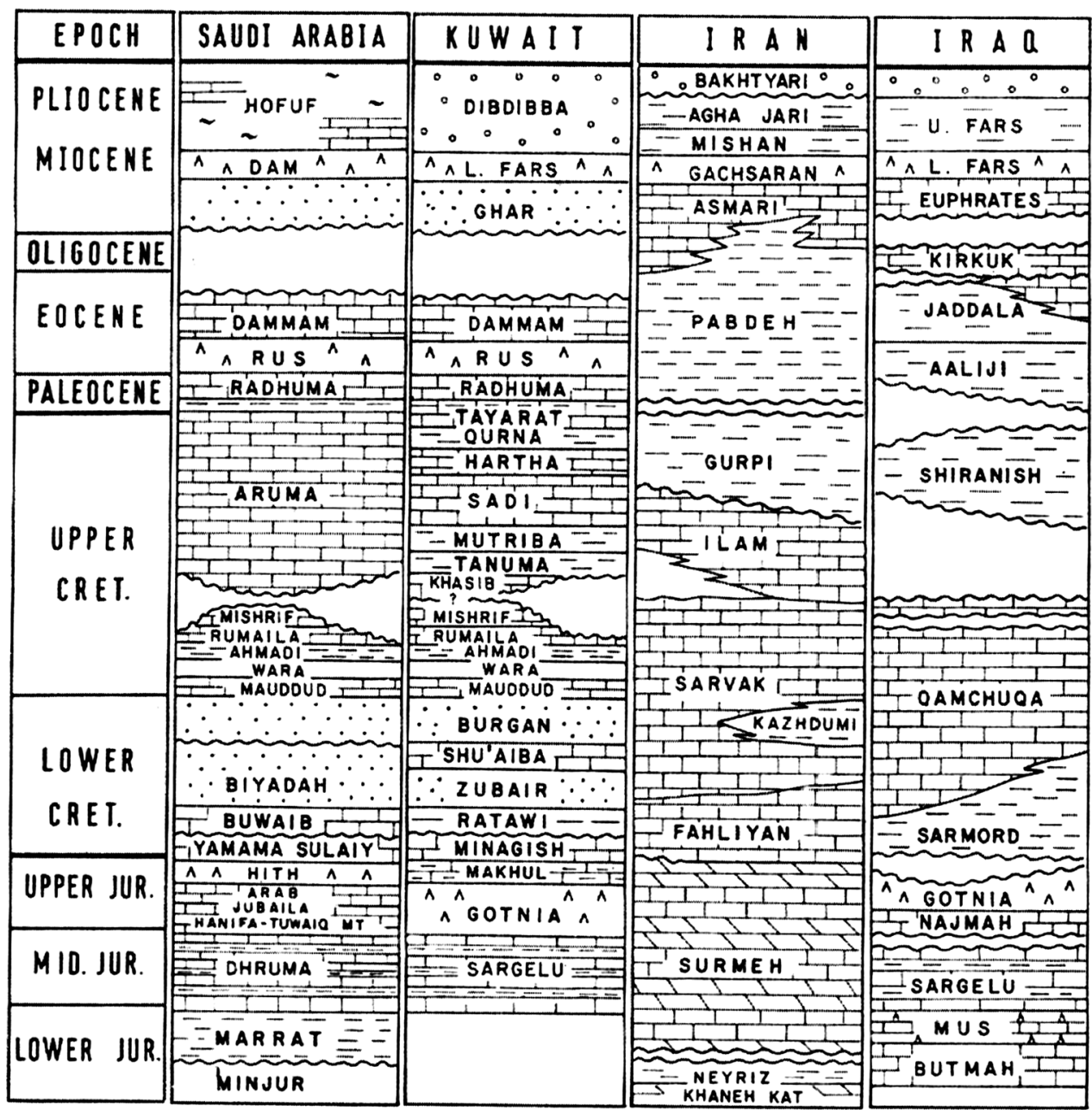

BASE $\mathrm{RL}$ mDMD

$\begin{array}{ll}\text { Calcareous Sandstone, very weak-weak } & -24 \\ \text { Gypsiferous / Calcareous Sandstone, very weak-weak } & -28.5\end{array}$

Calcisiltite, occasionally congolmeritic, very weak-mod. weak sequence, which ranges in thickness from 80 to $100 \mathrm{~m}$ from east to west across the country and from $100 \mathrm{~m}$ to almost zero thickness between the northern boundary and the $\mathrm{Al}$ Zawr escarpment. This formation consists of sands and gravel underlain by consolidated sandstones, conglomerates and siltstones. Below the Dibdibba formation 
Table 1 Summary of recommended ultimate skin friction values for Dubai deposits [8]

\begin{tabular}{lll}
\hline Stratum & Elevation (MDMD) & Ultimate skin friction (kPa) \\
\hline $\begin{array}{l}\text { Very dense/dense sands above } \\
\text { rockhead (stratum 1) }\end{array}$ & Transition zone above rockhead & 100 (maximum) \\
Upper sandstone (stratum 2) & Rockhead to -10 & 280 \\
Conglomerate (stratum 3/4) & -10 to -18 & 440 \\
\hline
\end{tabular}

are the lower Fars conglomeratic sandstones, variegated shale and thin fossiliferous limestones having a thickness of $60-120 \mathrm{~m}$, and then the Ghar formation, which is about $170 \mathrm{~m}$ thick and consists of partly cemented coarse pebbly sandstones, with minor beds of shale near the base.

In south Kuwait, the strata above the Eocene are known as the Kuwait group. This is a thick bed of sandstones, sands and some shale, with a thickness that varies between about 5 and $200 \mathrm{~m}$. The upper part of the Eocene sequence, the Dammam limestone, consists of about $200 \mathrm{~m}$ of soft chalky limestone and hard dolomitic limestone, with a chert cap that may be up to $10 \mathrm{~m}$ thick in some areas.

Abdullah and Kamal [1] have reported the occurrence of sinkholes arising from the presence of karstic limestone underlying 35-40 m of overburden at an urbanized site in Kuwait. They present an analysis of the causes of these sinkholes and discuss the consequences for future developments. Their investigations have identified similar conditions in other parts of the eastern coastline of the Arabian Peninsula, which had experienced similar problems with sinkholes.

Saleh et al. [30] give a more detailed description of the geological origin of the coastal "sabkha" deposits in northern Kuwait. Sabkhas are coastal flat areas that extend above the high tide level and consist of evaporate-rich sediments. These salt-bearing soils can be leached, resulting in a reduction in strength, penetration resistance and bearing capacity, and an increase in permeability, void ratio and compressibility [21].

Saleh et al. [30] provide a generalized stratigraphic profile which is reproduced in Fig. 5.

\section{Geotechnical profiles}

Saleh et al. [30] identify the following lithologic units within the coastal areas of Kuwait:
(a) Loose aeolian sand;
(b) Laminated gypsum and mud/silty sand;
(c) Mud/silty sand;
(d) Quartzose oolitic sand, silt and mud;
(e) Alternating oolites, pellets and shell layers;
(f) Gravelly sand and silt;
(g) Cross-bedded sandstone.

Ismael et al. [19] present shallow borehole details along a section $35 \mathrm{~km}$ long, running from Andalus in the west to Salmiya in the east, and these are reproduced in Fig. 6. The first two strata listed above can be identified. Average SPT values increase with depth from the surface to a depth of about $7 \mathrm{~m}$.

Ismael $[16,17]$ has presented geotechnical data on nearsurface cemented sand deposits Within the upper $3.5 \mathrm{~m}$, the effective stress strength parameters were within the following ranges: $c^{\prime}=31-190 \mathrm{kPa}, \phi^{\prime}=34.2^{\circ}-38.7^{\circ}$. The compression index ranged between 0.06 and 0.10 , while the range of the recompression index was $0.013-0.028$.

\section{Foundation design parameters}

Limited published information exists on foundation performance in Kuwait. Al-Sanad et al. [7] summarize data on Young's modulus obtained from pressuremeter tests (PMT), and plate load tests for a site in Kuwait City, and this data is reproduced in Fig. 7. The modulus values for first loading of the plate were reasonably consistent with the PMT test data, but significantly higher values were found from reloading and cyclic loading tests on the plate.

The results of some pile load tests carried out in Kuwait have been presented by Ismael and Al-Sanad [20] and Ismael [13, 17-18]. Typically, the skin friction values for relatively short bored piles in cemented sands are between 80 and $107 \mathrm{kPa}$, and are larger than those for driven piles (about $60 \mathrm{kPa}$ ), a characteristic that is not uncommon in soils with a relatively high carbonate content. For the short piles tested, there seems to be little difference between the values for compression and uplift, although for longer more compressible piles, it would be expected that the skin friction in uplift would be less than the value for compression. It was also found that, for small groups of bored piles at relatively close spacings, the group efficiency factor was greater than 1 , and for a 4-pile group at 3-diameter spacing, an efficiency factor exceeding 1.9 was observed.

Ismael [15] presented the results of lateral loading tests on single pile sand small pile groups. The piles were relatively short (up to about $5 \mathrm{~m}$ ) and located in cemented silty sands. Parabolic $p-y$ curves were obtained and it was found that ignoring the cohesion of the cemented sand resulted in an over-conservative prediction of load-deflection characteristics. However, for short piles, extensive wetting and 
Fig. 5 Generalized stratigraphic column for coastal areas in Kuwait [30]

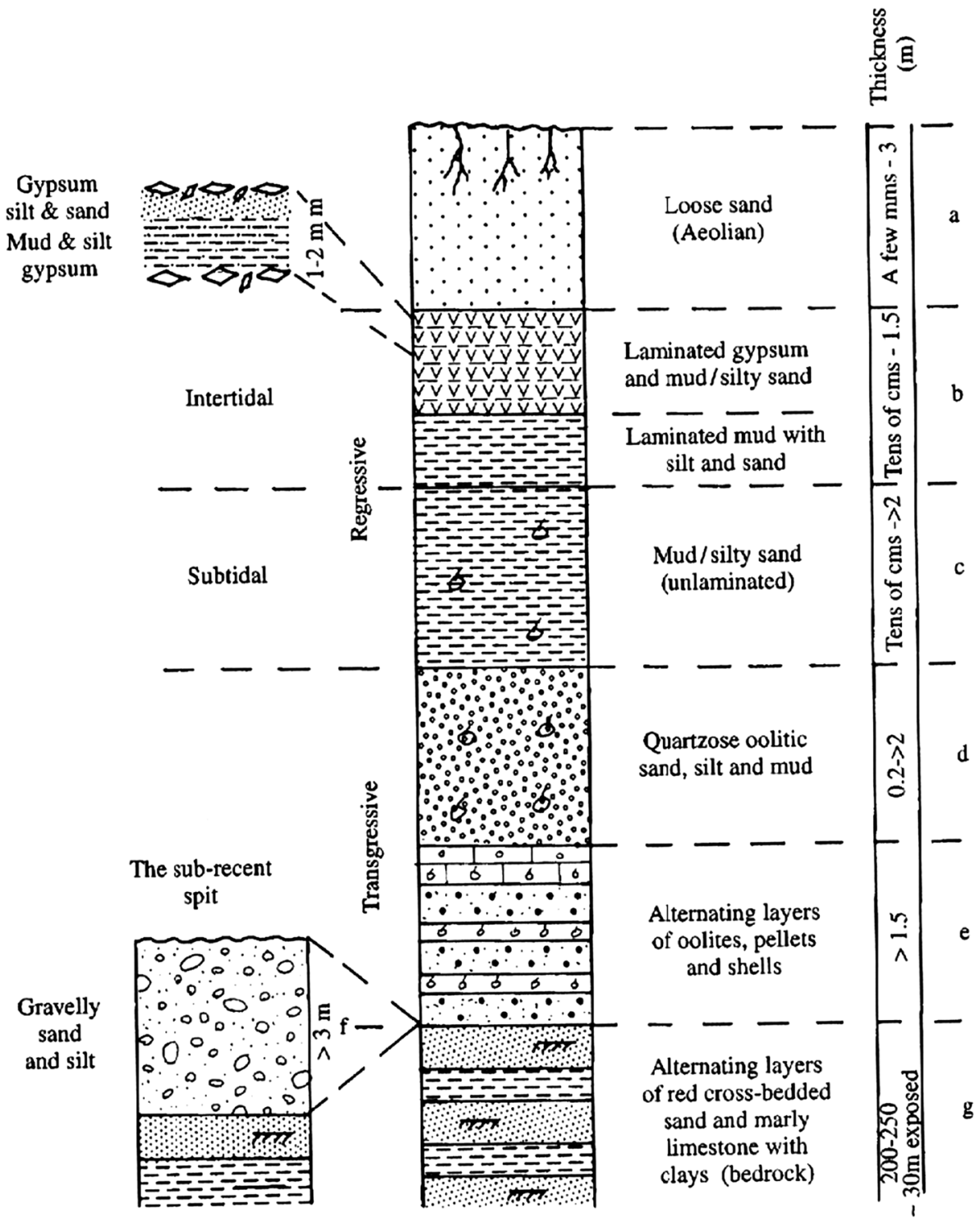

disturbance caused softening and partial loss of cementation of the near-surface soils, and it was recommended that a reduction of $30-40 \%$ in the cohesion be allowed for to reflect this effect.

\section{Qatar}

\section{Geology}

The Qatar peninsula is geologically a part of the Arabian Gulf basin, between the stable Arabian Shield of western Saudi Arabia and the mobile south-western Iranian belt. The structure of Qatar consists of an anticlinal arch with a north-south axis running through the centre of the country. The geological succession consists of a sequence of shallow water marine limestones and dolomites with interbedded clays, marls and shales of Tertiary age. These are overlain by Quaternary and Recent deposits, which are typically less than $10 \mathrm{~m}$ thick and consist of gravelly sands, weakly cemented, with local patches containing secondary gypsum.

A summary of the Tertiary geological strata of Qatar is presented in Table 2. The Simsima Limestone of the Upper Damman forms the surface of almost all of Qatar and comprises chalky limestone with varying thicknesses of dolomitic limestone. This deposit is generally surface-hardened over most of its outcrop, but may also contain irregular pockets of clay in the Doha area.

The Lower Damman deposits generally comprise chalky limestone with a shale layer (Midra Shale) present in the southern two-thirds of Qatar. A reduction in calcium carbonate and an increase in magnesium carbonate are apparent in the transition between the Lower Damman and the underlying Rus Formation. 

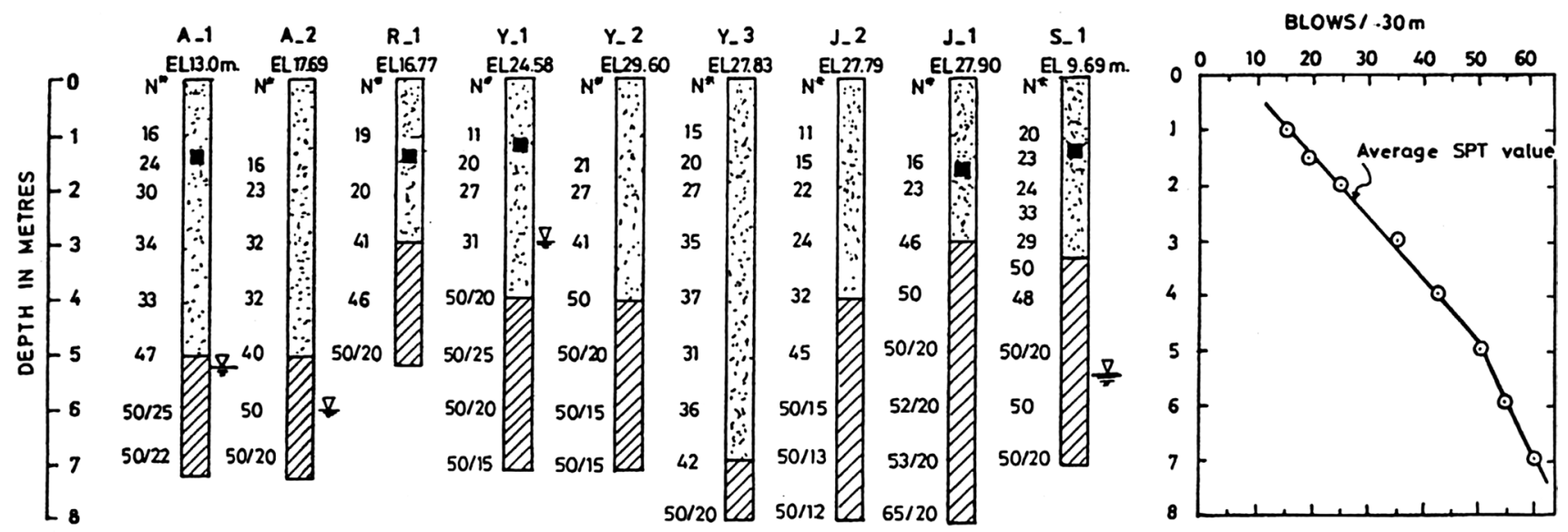

WIND BLOWN SAND: BROWN CALCAREOUS DRY FINE SAND WITH TRACES

OF SILT \& COARSE SANO (SP $\rightarrow$ SM)

Z BROWNISH GREY CALCAREOUS SILTY FINE TO MEDIUM CEMENTED SAND

WITH TRACES OF COARSER FRACTIONS $(S M-S C)$

block sampling locations

* spt value ( blows per $30 \mathrm{~cm}$. unless otherwise indicated )

Fig. 6 Typical shallow geotechnical profiles in Kuwait [19]

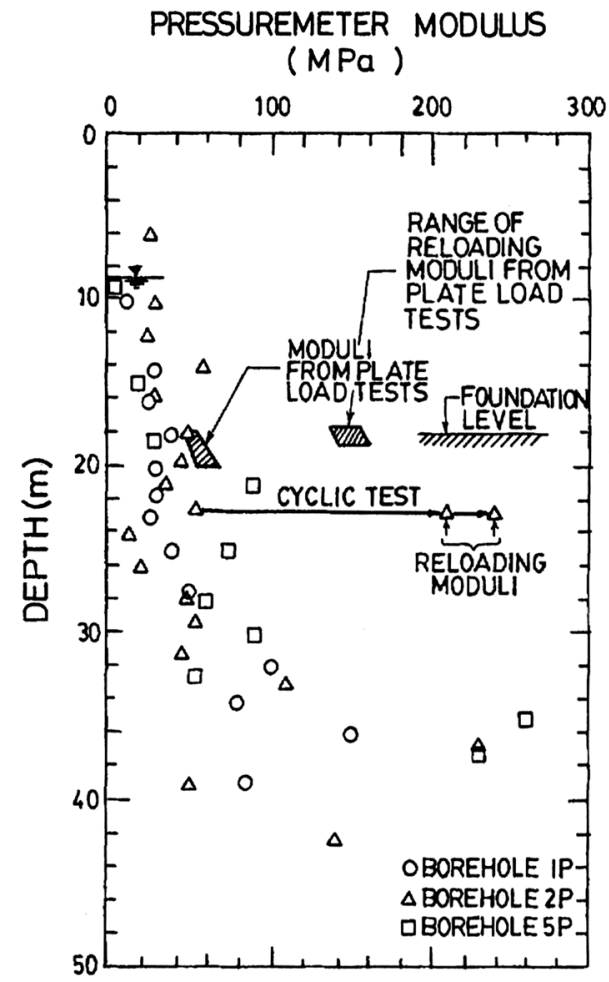

Table 2 Typical tertiary geological succession in Qatar

\begin{tabular}{|c|c|c|}
\hline Epoch & Formation & Member \\
\hline \multirow[t]{2}{*}{ Pliocene/Miocene } & Upper Dam & - \\
\hline & Lower Dam & - \\
\hline \multirow[t]{3}{*}{ Eocene } & Upper Damman & $\begin{array}{l}\text { Abarug } \\
\text { Dolo- } \\
\text { mitic } \\
\text { Lime- } \\
\text { stone } \\
\text { Abarug } \\
\text { Marl } \\
\text { Simsima } \\
\text { Dolo- } \\
\text { mite and } \\
\text { Lime- } \\
\text { stone }\end{array}$ \\
\hline & Lower Damman & $\begin{array}{l}\text { Dukhan } \\
\text { Alveolina } \\
\text { Lime- } \\
\text { stone } \\
\text { Midra and } \\
\text { Saila } \\
\text { Shales } \\
\text { Fhaihil } \\
\text { Velates } \\
\text { Lime- } \\
\text { stone }\end{array}$ \\
\hline & Rus Formation & - \\
\hline Palaeocene & Umm Er Radhuma & _- \\
\hline
\end{tabular}


The Rus Formation can be divided into two provinces at the centre of Qatar, a carbonate facies and a sulphate facies. In the latter (in which Doha is situated), the typical depositional cycle (about $5 \mathrm{~m}$ thick) is typically as follows:

- Greenish clay $1.0 \mathrm{~m}$ thick

- Gypsum with clay/marl 3.3 m thick

- Limestone $0.7 \mathrm{~m}$ thick.

The sulphate facies of the Rus Formation was deposited in a subsiding area of relatively rapid and turbid evaporitic sedimentation. Typically, the core recovery during drilling may reduce from about $80 \%$ in the Damman Formation to less than $50 \%$ in the gypsum-bearing Rus Formation. In the northern region of Qatar, the Rus Formation may be about $30 \mathrm{~m}$ thick, but increases to the order of $100 \mathrm{~m}$ thick towards the west and south-east.

The underlying Umm Er Radhuma Formation contains limestone and dolomite.

\section{Geotechnical profiles}

There is little or no published information on geotechnical profiles and properties for sites in Qatar. A typical geotechnical profile in Doha at the site of a high-rise building is shown in Fig. 8. Below the Simsima Limestone and the Midra Shale, the uniaxial compressive strength of the various strata is low to very low, even at depths in excess of $100 \mathrm{~m}$.

\section{Foundation design parameters}

Poulos [27] has described the design process for a tall building in Doha, Qatar. This high-rise tower is still under construction and will be in excess of $400 \mathrm{~m}$ tall, with 74 storeys and three basement levels. It is founded on a pile-supported raft, with piles extending 40-50 m below the base of the raft. A low-rise podium area is to be located adjacent to the tower.

A total of 23 boreholes were drilled at the site, to depths of up to $120 \mathrm{~m}$. The in situ testing consisted of the following:

- SPT tests in upper superficial deposits and at some lower levels where the rock was weak and core recovery was poor.

- Geophysical investigations, including cross-hole tomographic imaging, downhole seismic surveys, a 750 point microgravity survey and a 6-line resistivity survey.
Fig. 8 Typical Geotechnical profile in Doha, Qatar

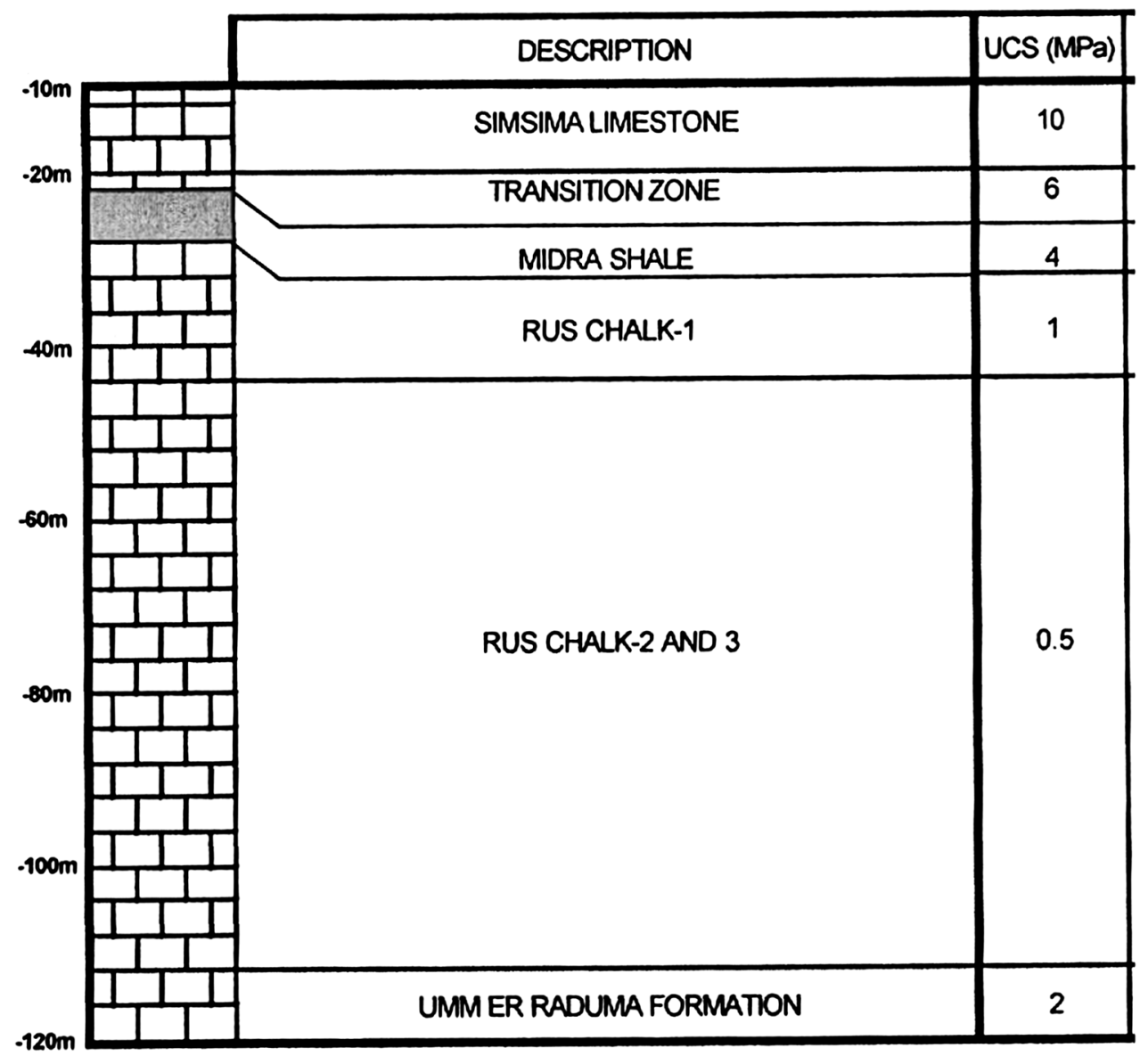


- 53 pressuremeter tests within four of the boreholes beneath the tower, to measure strength and deformation characteristics of the various strata.

- 53 packer tests within seven boreholes, to measure permeability within the various strata.

- 6 standpipes to monitor the groundwater levels.

An extensive program of laboratory testing was undertaken, both conventional and specialized. The conventional tests included particle size distribution, unconfined compressive strength, point load strength, and carbonate content tests. The specialized tests included the following:

- Stress path triaxial tests, to measure deformation properties of the strata.

- Resonant column tests, to measure the small-strain modulus values of the rock core samples.

- Cyclic undrained triaxial tests, to assess the effects of cyclic loading on the strength and stiffness of rock core samples.

- Constant normal stiffness direct shear tests, to measure the pile-soil skin friction and the effects of cyclic loading.

A program of pile load testing was also undertaken, consisting of four compression tests on piles of various length (3 with $1.5 \mathrm{~m}$ diameter and one with $0.9 \mathrm{~m}$ diameter) and two tension tests on piles about $26 \mathrm{~m}$ long, one $0.9 \mathrm{~m}$ in diameter and the other $0.75 \mathrm{~m}$ diameter. On the basis of the above information, a geotechnical model was progressively developed for the site. The site was quite uniform laterally, and so only a single model was necessary. Table 3 summarizes the final model adopted by the author for the foundation design verification process. The modulus and skin friction parameters were influenced heavily by the results of the pile load tests. It will be noted that the strata generally become weaker with increasing depth, and no reliable end bearing stratum was found within an acceptable depth. For the raft, an ultimate bearing pressure of $2.1 \mathrm{MPa}$ was assessed.

\section{Saudi Arabia}

\section{Geology}

Descriptions of the geology of Saudi Arabia are given by Evans [10], Oweis and Bowman [25] and Al-Refeai and AlGhamdy [6], among others. As illustrated in Fig. 2, Saudi Arabia is divided into two basic geological zones:

1. The Arabian Shield, a Precambrian basement complex which underlies about one-third of the Kingdom and extends from the western coast for about $500-600 \mathrm{~km}$ towards the east. The rocks within this area are mostly igneous and metamorphic, and form a dome-shaped topography that is often covered by thin deposits of alluvial sands and gravels.

2. The Arabian Shelf, which lies east of the Arabian Shield. Sedimentary rocks, which range in age from Cambrian to Quaternary, dip gently towards the Arabian Gulf in the east, and towards the depression of Rub Al-Khali in the south. These sedimentary rocks are mostly limestone, sandstone, siltstone and shales. The terrain is often covered by loose Aeolian deposits and sometimes with thick strata of wadi alluvium or residual soils.

\section{Geotechnical profiles}

Many areas in the Kingdom of Saudi Arabia are associated with problematic soils and complex subsoil conditions. Typical problems include expansive soils, collapsing soils, sabkha deposits (salt-bearing soils), loose Aeolian deposits, and shifting sand dunes [6]. Sabkha deposits pose a particular problem in foundation design, as their salt content can adversely affect the durability of structures and foundations

Table 3 Geotechnical model adopted for verification of tower foundation design

\begin{tabular}{|c|c|c|c|c|c|c|c|}
\hline Material & $\begin{array}{l}\text { RL at top of } \\
\text { stratum }^{b}(m \\
\text { QNHD) }\end{array}$ & Thickness (m) & $\begin{array}{l}\text { Typi- } \\
\text { cal UCS } \\
(\mathrm{MPa})\end{array}$ & $\begin{array}{l}\text { Young's modulus } \\
{[\mathrm{MPa}] \text { (short term) }}\end{array}$ & $\begin{array}{l}\text { Young's modulus } \\
\text { [MPa] (long-term) }\end{array}$ & $\begin{array}{l}\text { Ultimate skin } \\
\text { friction }^{\mathrm{a}}(\mathrm{kPa})\end{array}$ & $\begin{array}{l}\text { Ultimate } \\
\text { end bearing } \\
(\mathrm{MPa})\end{array}$ \\
\hline Limestone & -5 & 15 & 15 & 1650 & 1500 & 560 & 15 \\
\hline Transition zone & -20 & 3 & 4 & 720 & 600 & 675 & 12 \\
\hline Shale & -23 & 3 & 4 & 720 & 600 & 525 & 4.6 \\
\hline Chalk-1 & -26 & 20 & 0.6 & 315 & 150 & 400 & 4.8 \\
\hline Chalk-2 & -46 & 66 & 0.2 & 315 & 150 & 250 & 3.4 \\
\hline Umm Er Radhuma & -112 & $>25$ & 2 & 1100 & 1000 & - & - \\
\hline
\end{tabular}

${ }^{\mathrm{a}}$ For compression loading. Values for tension were reduced from these values

${ }^{\mathrm{b}}$ The raft base level varied between from 15.6 to $21.6 \mathrm{~m}$ below existing ground level (deeper levels below lift pits) 
that are in contact with the soil. They are highly heterogeneous and exhibit behaviour ranging from non-plastic to highly plastic, with liquid limits as high as $80 \%$ or more. More detailed information on sabkha soils is provided by James and Little [22], Hossain and Ali [13], Akili [3] and Akili and Torrance [4].

In coastal areas, coral limestone formations, which, in their natural condition, are soft, non-homogeneous and porous, and can be challenging for foundation designers. In the central region, a thick stratum of highly weathered limestone with calcite crystals can contain solution cavities and solution collapse breccia. The city of Riyadh has particular problems with limestone cavities.

Oweis and Bowman [25] have presented typical geotechnical profiles for four zones:

1. Zone A: Western coastal plains, subdivided into Zone A1, generally covered by soft sabkha coastal deposits, and Zone A-2, covered by alluvial deposits from the coast to the Arabian Shield. Figures 9 and 10 show subsurface conditions for these two sub-zones. As stated by the authors, "typical" profiles in these areas can be misleading because of the variability of the ground conditions; the soft and loose coastal soils can range in thickness from a few metres to more than $20 \mathrm{~m}$.

2. Zone B: Arabian Shield, extending north and east to the coastal plains of the Gulf. Figure 11 shows typical profiles in this area. There is usually a shallow cover of soil over igneous or metamorphosed rock, with varied degrees of weathering.

3. Zone C: sedimentary rocks from the Shield to the coastal plains of the Gulf (Fig. 12). Geotechnical problems occurring in this area include solution cavities in limestone bedrock, the presence of gypsum-bearing soils in basins and poorly drained areas, the presence of inland sabkhas, and the potential variability of ground conditions at the same site, for example, rock versus residual clay soil.

4. Zone D: the eastern coastal plain (Figs. 13 and 14). This area is characterized by the presence of salt-bearing soils or sand dunes. Typically, in low-lying areas near the coast, there is a relatively shallow layer of soft and loose deposits overlying medium dense to dense sands below. Layers of stiff to hard clays or lenses of rock can be encountered in thicknesses up to several metres. Artesian groundwater conditions may also be encountered.
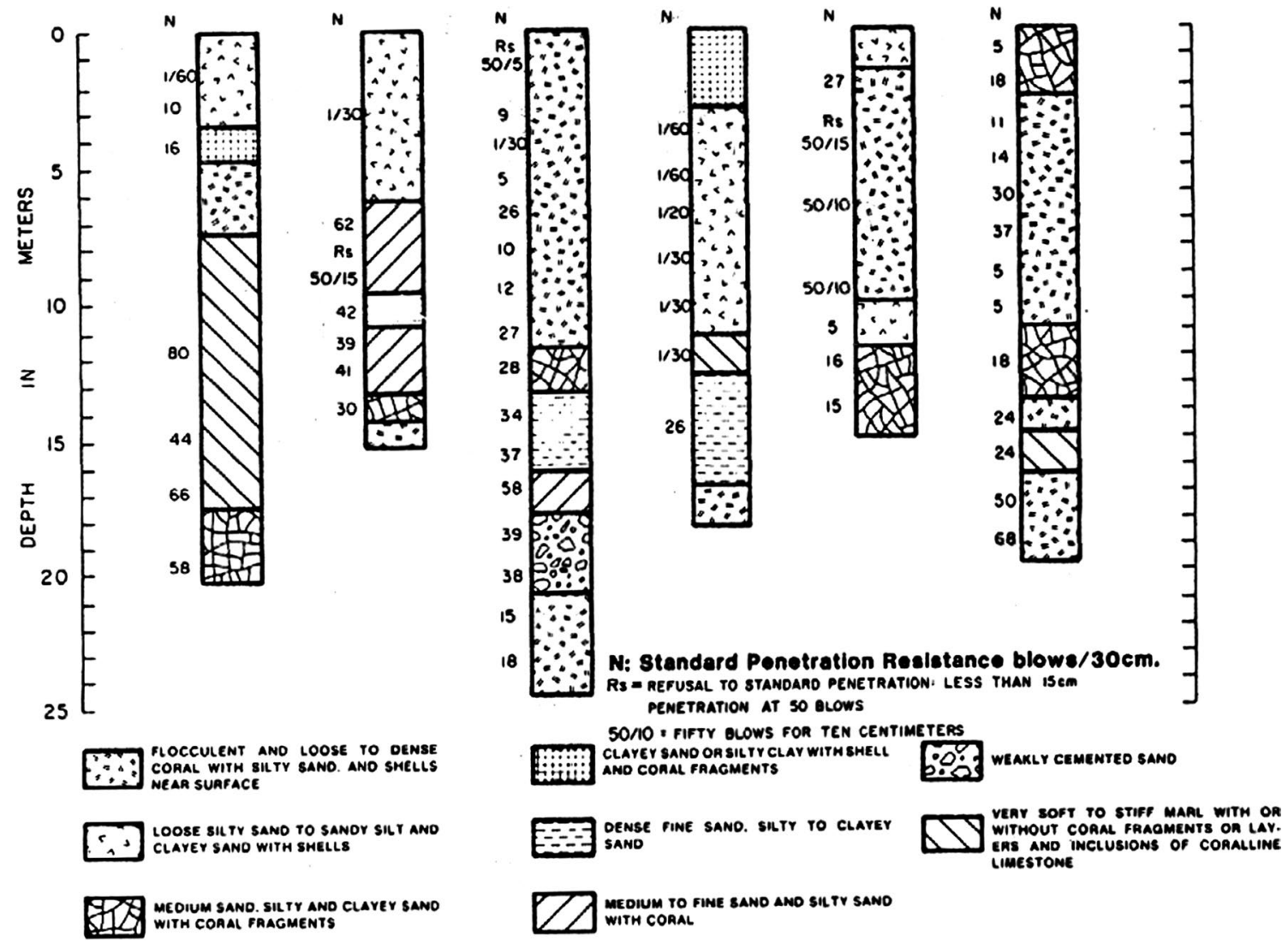

Fig. 9 Subsurface conditions for Saudi Arabia, Zone A-1 [25] 
Fig. 10 Subsurface conditions for Saudi Arabia, Zone A-2 [25]

Fig. 11 Subsurface conditions for Saudi Arabia, Zone B [25]

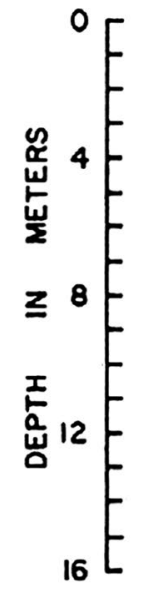

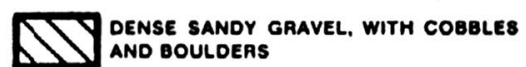

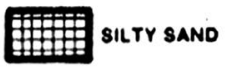

PifY hand Siltr clar

E- Dense sano

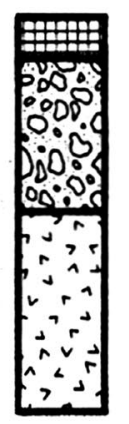

11.1

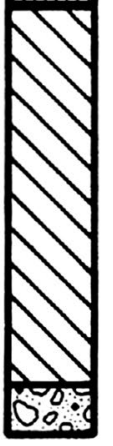

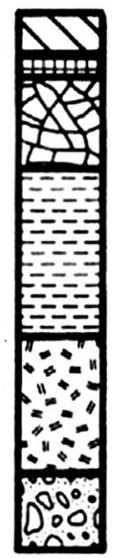

-1
-1
-1
-1
-1
-1

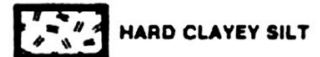

D.:. W. WEATHERED CORALLINE LIMESTONE

$\left[\begin{array}{c}2 \\ 2 v\end{array}\right]$ OENSE SANOY GRAVEL

D dense gravelly sano
(15)

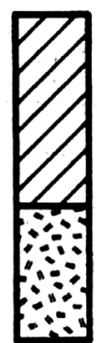

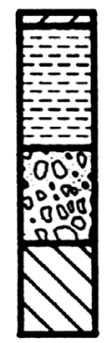
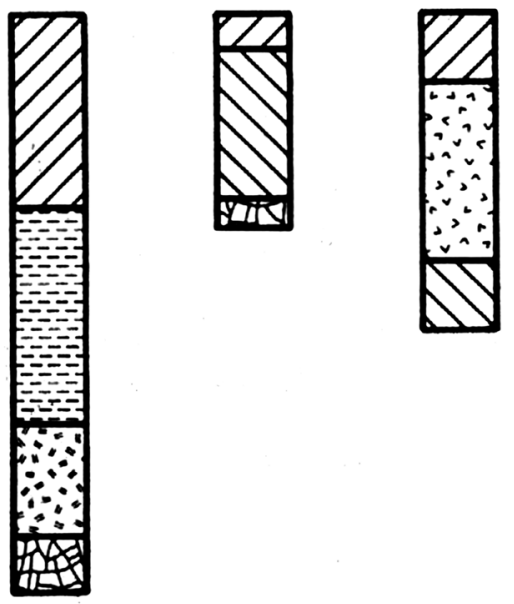

DT:? HARO CLAY

DENBE SAND TO OAAVELLY SANO OA BILTY AND CLAYEY Sand (RESIDUAL SOIL OA ALLUVIUMM)

- SEDIMENTARY Rock (ERECCIA. SAND. (OENERally GaANite)

OUgh sanostone

$E=-7$ GAAVEL AND COBBLES

piff aneiss

Doranite 


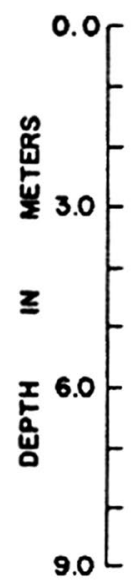

PSOFt ro maro limestone

D HARD CLAY IAESIDUAL SOIL FROM LIMESTONE). BLOCKY. OR BECOMES BLOCKY UPON EXTRACTION

OOD LOSE GRAVELIY SANO WITH GYPSUM

S.J OENSE SAND TO SILIY SANO WITH
LIMESTONE FRAGMENTS
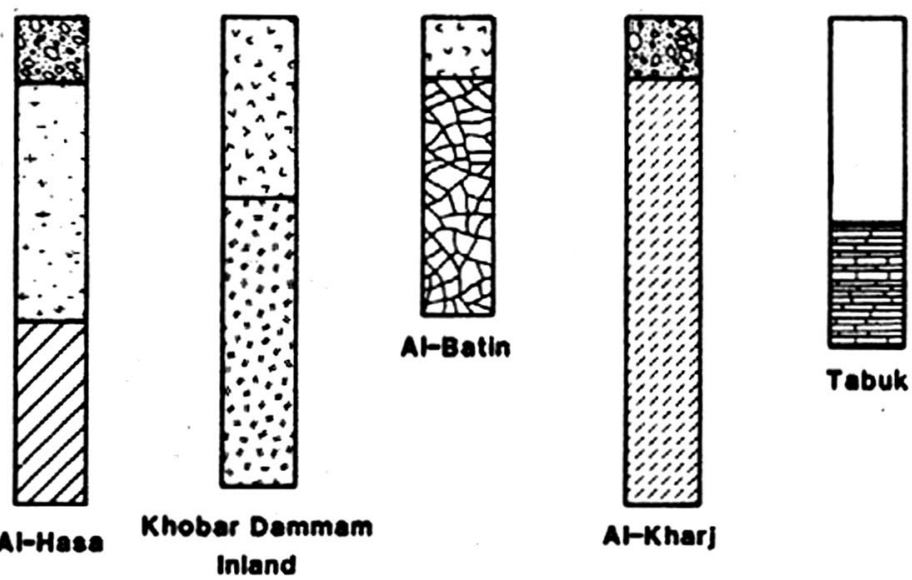

Tabuk

AtKhar]

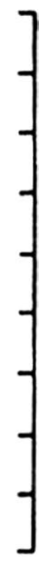
APHANITIC ANO DOLOMITICLIMESTONE.
WITH GYPSUM ANO SIITY CLAY LAYEAS.
CALCITE VEINS. CAVERNOUS

SOIL.LIKE MARLY LIMESTONE. WITH LAYEAS OA BOULDERS OF MARDER CIMESTONe. LaYsas of SHaLE OR

7777 well graoco oense ganvelLY sano. EXß] WELL GRAOED OENSE GRAVELIY

LOOSE TO DENSE GYPSIFEROUS SAND ANO ORAVEL Q7D GARO conglomeante oven con.

SANOSTONE OR SHALE

Fig. 12 Subsurface conditions for Saudi Arabia, Zone C [25]

Fig. 13 Subsurface conditions for Saudi Arabia, Zone D, offshore, Jubail [25]
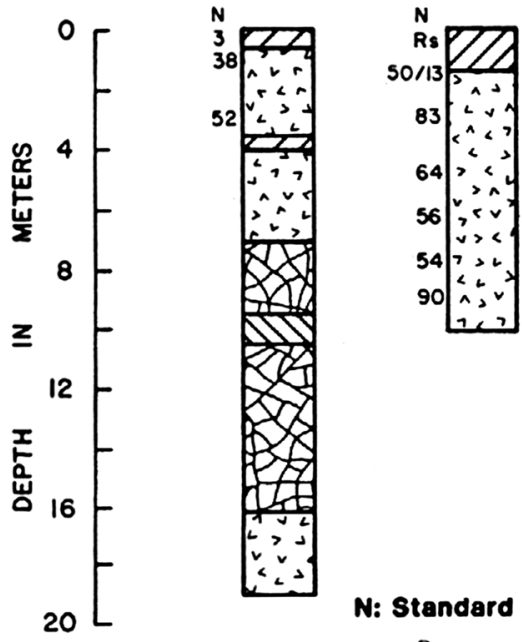

[ras

H. Marl (CALCAREOUS clayey SILT. SANOY SILT) calcareous sandostone or lime.
stone with voios
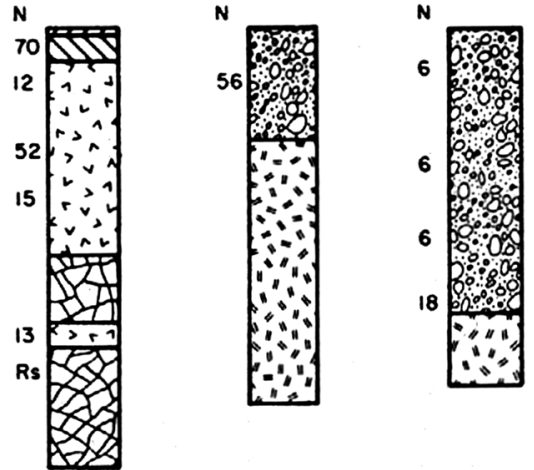

N: Standard Penetration Reslstance blows $/ 30 \mathrm{~cm}$.

Rs = REFUSAL TO STANDARD PENETRATION: LESS THAN $15 \mathrm{~cm}$ PENETRATION AT 50 BLOWS

SO/IO = FIFTY OLOWS FOR TEN CENTIMETERS 


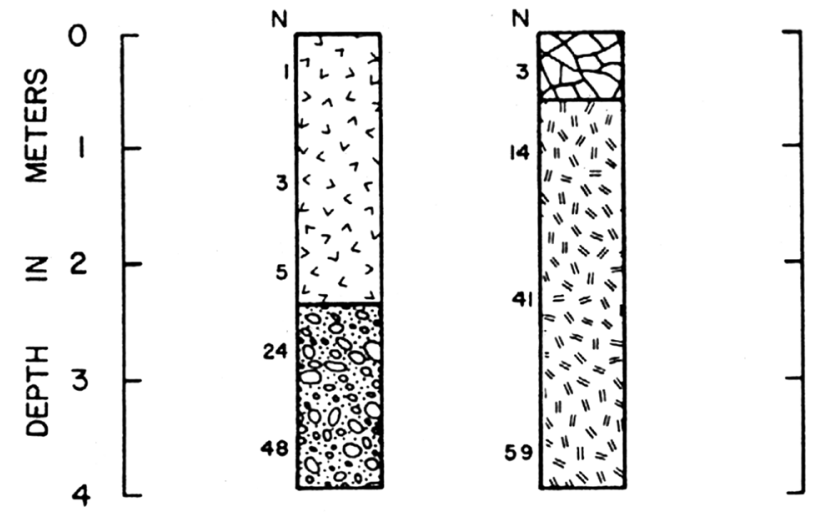

N: Standard Penetration Resistance blows $/ 30 \mathrm{~cm}$.

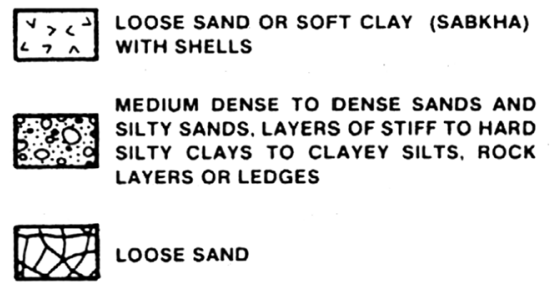

" " " MEDIUM DENSE TO DENSE SAND (SAND

Fig. 14 Subsurface conditions for Saudi Arabia, near-shore deposits, Zone D [25]

Table 4 Results of plate load tests on Sabkha (After [6])

\begin{tabular}{lcc}
\hline Quantity & Dry soil & Saturated soil \\
\hline Maximum pressure (kPa) & 1250 & 1000 \\
Young's modulus (MPa) & 70 & 25 \\
\hline
\end{tabular}

\section{Foundation design parameters}

\section{Shallow foundations}

There appears to be relatively little quantitative information on foundation performance in Saudi Arabia available in the published literature. Al-Refeai and Al-Ghamdy [6] report the results of plate load tests ( $300 \mathrm{~mm}$ diameter) on sabkha. Table 4 provides an interpretation of their data and indicates that saturation can have a significant effect on the engineering properties. The Young's modulus values in Table 4 appear to be relatively high for a soil deposit whose compression index can range between about 0.4 and 0.95 .

\section{Deep foundations}

Hagenaar and van Seters [12] have presented information on driven piles in coral rock and carbonate soils along the Red Sea coast of Saudi Arabia, near Jeddah and Yanbu. Dynamic

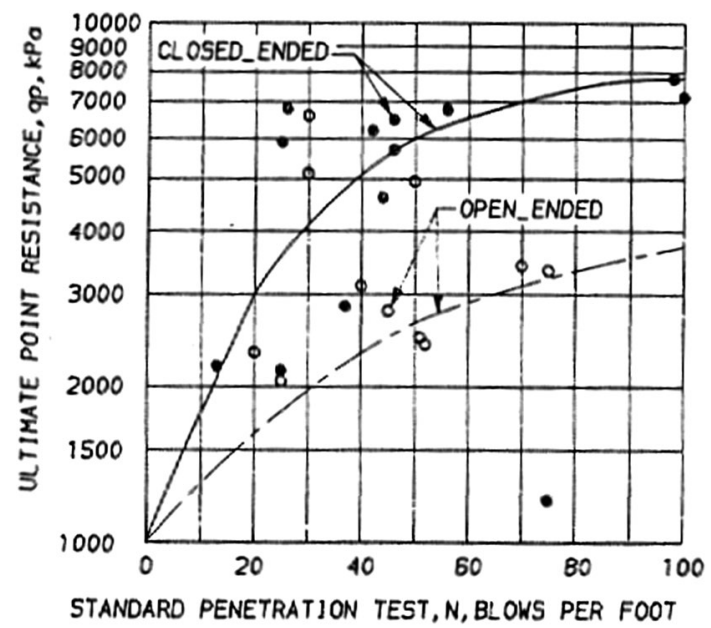

Fig. 15 End bearing resistance versus SPT-N for driven piles in coralline deposits [12]

pile testing indicated very low values of skin friction that did not increase significantly with depth, and a value of $20 \mathrm{kPa}$ was adopted for design purposes. Limiting values of end bearing resistance were correlated with SPT-N values, as shown in Fig. 15. Significantly larger values were developed for closed-ended piles than for open-ended piles.

Akili [2] has also reported the results of tests on steel tube piles, $1.4 \mathrm{~m}$ in diameter and $19 \mathrm{~mm}$ wall thickness, driven into coral and coralline sand deposits along the Red Sea coast. For piles penetrating about $30-45 \mathrm{~m}$, very low average values of skin friction were experienced, ranging between about 12 and $20 \mathrm{kPa}$. End bearing values for closed-ended piles were also lower than anticipated, ranging between about 1.5 and $4 \mathrm{MPa}$. Clearly, the relatively loose nature of these deposits resulted in decreases in lateral pile-soil stress during installation of the piles, and a manifestation of the "friction fatigue" problem.

Tonnison et al. (1989) carried out measurements on $3.5 \mathrm{~m}$ diameter prestressed concrete cylinders grouted into weak Tertiary rocks located offshore between Saudi Arabia and Bahrain. They concluded that to obtain agreement between measured and calculated deflections, a Young's modulus equal to about twice the pressuremeter modulus should be used. The pressuremeter modulus was in turn related to the unconfined compressive strength, $q_{\mathrm{u}}$, of the rock, and ranged between 50 and $200 q_{\mathrm{u}}$, with an average value of 100 .

\section{Oman}

\section{Geology}

Robertson et al. [29] and Pollastro [26] present a detailed account of the geology and tectonics of the Oman region. 
Oman is located on the south-eastern margin of the Arabian plate and is close to the boundaries of the Iranian, Indian,

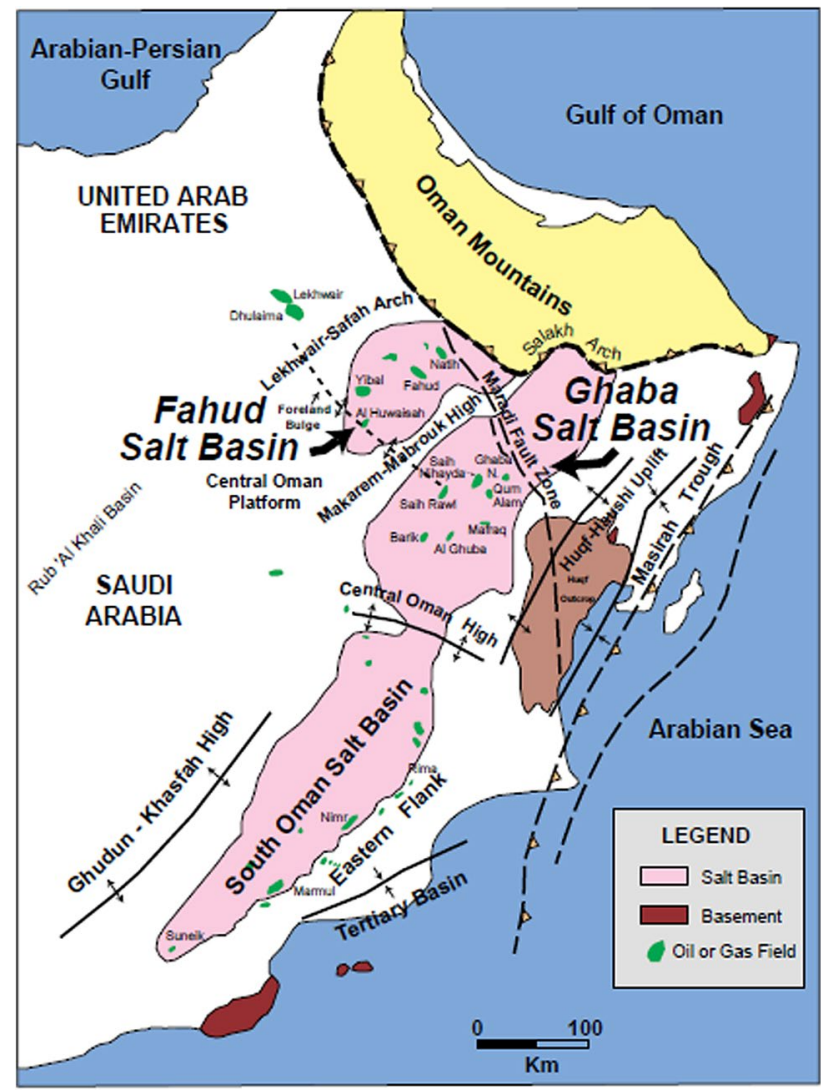

Fig. 16 Geological areas of Oman [26] and African plates. Consequently, plate movements have resulted in complex structural, sedimentation, and burial histories. Oman is tectonically bounded on the south by the Gulf of Aden spreading zone, to the east by the Masirah Transform Fault and the Owen Fracture Zone Trough, and to the north by the complex Zagros-Makran convergent plate margin, compression along which produced the Oman Mountains [24].

Precambrian metamorphic and igneous basement rocks are known from a limited number of wells and from exposures of bedrock along the Huqf-Haushi Uplift on Oman's eastern margin (see Fig. 16). The Ghaba Salt Basin, South Oman Salt Basin, and to a lesser extent, the Fahud Salt Basin, are part of a series of subsiding rift basins stretching from India and Pakistan across the Arabian Shield to central Iran that formed during the Infracambrian and lower Cambrian (about $600-540 \mathrm{Ma}$ ). These rift basins were formed by extension from strike-slip movement of the Najd transform fault system which ultimately dislocated the Arabian plate some $300 \mathrm{~km}$ to the east. A typical generalized cross section across the Ghaba and Fahud Salt Basins is shown in Fig. 17.

The sedimentary section in the hydrocarbon producing provinces of Oman is made up of rocks ranging from Proterozoic to Recent. Clastic rocks comprise most of the lower Paleozoic part of the section, whereas, the Permian through Tertiary part of the section are predominantly carbonate rocks and reflect climatic variations due to Omanís changing paleolatitude through geologic time.

The Huqf Supergroup contains several clastic and carbonate source rocks which form the basis of the primary petroleum systems for hydrocarbons produced throughout Oman.
Fig. 17 Typical geological cross-section of Oman [26]

\section{Southeast}

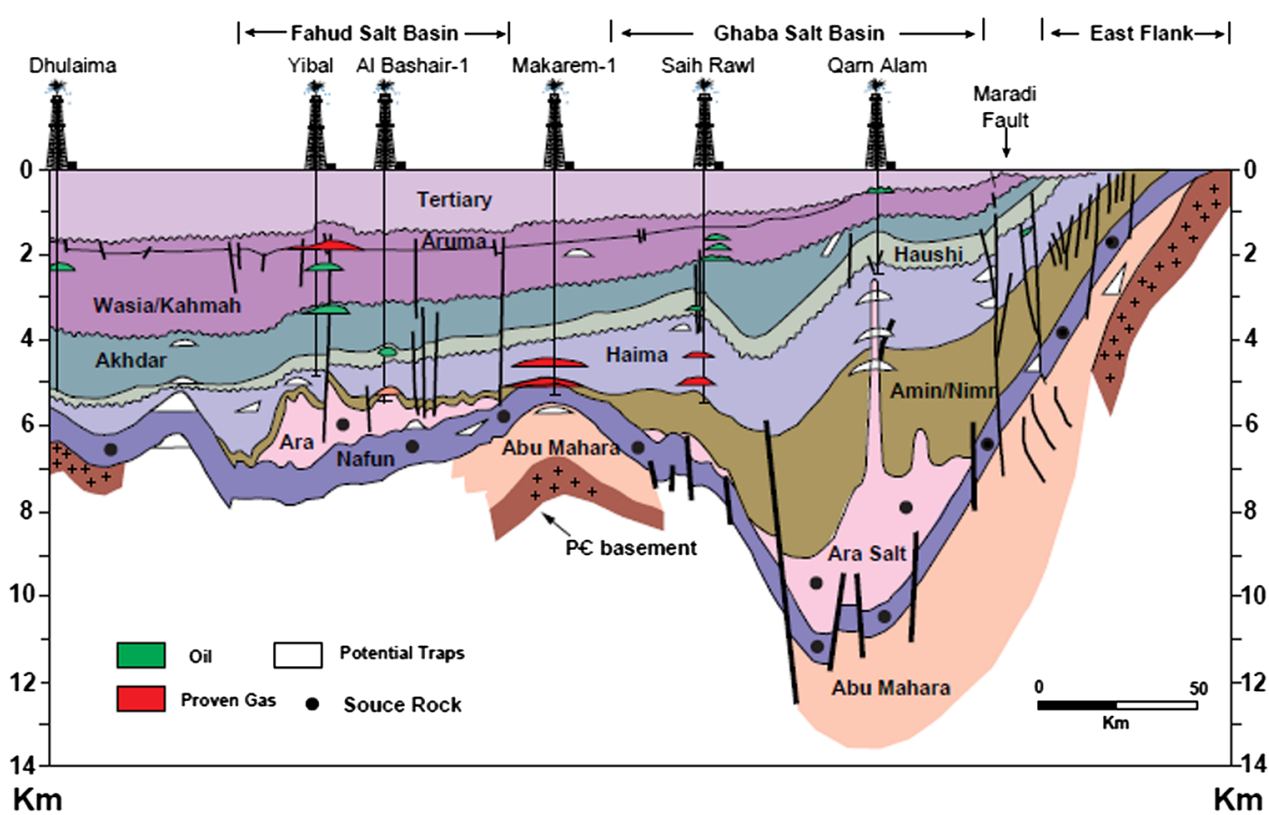


The Cambrian Ara Formation is a carbonate/evaporite sequence with thick salt deposits (up to $1000 \mathrm{~m}$ ). The thick Ara evaporites were deposited in geographically-restricted basins during periods of low relative sea level where stratified, anoxic conditions periodically prevailed and organicrich sediments and salt were deposited. The lower Paleozoic section along the southern rim of the Arabian platform is comprised of mainly continental clastics, with some marine intercalations, which form important hydrocarbon reservoirs in the Ghaba and Fahud Salt Basins. A thick sequence of rift fill terrigenous and shallow-marine siliciclastics of the Haima Supergroup overlies the Ara Formation.

In the Ghaba Salt Basin, sediments of the Haima Supergroup fill and cover the margins of the basin reaching thicknesses up to $6 \mathrm{~km}$ along the central axis [9]. Pre-existing, highly variable topography caused major variations in sediment infill. Numerous unconformities are present throughout the Paleozoic in Oman. Two major and very broad uplift and erosional events in eastern Oman removed most of the Silurian and Lower Devonian sediments and the interval between mid-Devonian and Upper Carboniferous; these erosional events are recognized in deep wells from the main producing fields in the Ghaba and Fahud Salt Basins. Late Carboniferous time is marked in Oman by glaciation and subsequent deposition of glacial clastics of the Gharif Formation.

The Tertiary deposits comprise the Umm Er Radhuma, Rus and Damman formations, and these are underlain by the Aydim, Zalumah and Ashawq formations of late Eocene and Oligocene age.

The Quaternary deposits are heterogeneous in nature and of different origins. They comprise alluvial deposits, colluvial deposits, Aeolian deposits and travertine and littoral marine deposits.

\section{Geotechnical profiles}

There appears to be relatively little published information on the near-surface stratigraphy in Oman. Al-Rawas and Qarnaruddin [5] identified expansive soils at different sites in northern Oman, between 35 and $45 \mathrm{~km}$ west of Muscat. They found that smectite is the major clay mineral, but that the expansive soils were influenced by the composition of the parent rocks. The expansive soils and rocks are generally variable with changes in colour, structure and lithology. A typical shallow profile containing expansive clay is shown in Fig. 18 [5].

Aeolian and reworked calcareous sediments known as "desert fill" can be present in low-lying topographic depressions, and this desert fill occurs as a light greenish-brown poorly sorted sand comprising carbonate and ophiolitic material of the conglomerates.

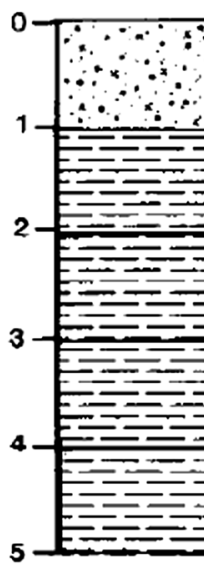

Brownish grey, dense, siightly silty, fine to coarse SAND and GRAVEL with cobbles.

Yellowish brown, very stiff to hard. very silty CLAY with occasional thin layers of gypsum crystals.

Fig. 18 Typical expansive soil profile in northern Oman (Al-Rawas and Qarnaruddin [5])

\section{Foundation design parameters}

For the expansive clays found in northern Oman, Al-Rawas and Qarnaruddin [5] reported the following plasticity characteristics from 12 samples:

Liquid limit: 47-82;

Plastic limit: 14-44;

Plasticity Index: 15-67;

Natural water content: 10-25\%;

Free swell: 45-95\% (from 4 samples).

No information on strength or compressibility characteristics were provided.

Tarawneh et al. [31] have presented the results of in situ testing at a site near the Arabian Sea in Muscat. CPT and pressuremeter testing were carried out to provide data for the prediction of shallow foundation settlements and comparisons with measured settlements from load tests. The site consisted of a profile of gravelly sand, clean sand and silty sand, which had been subjected to dynamic compaction to improve its engineering properties. The water table was between 0.75 and $1.2 \mathrm{~m}$ below ground level.

Figures 19 and 20 show the CPT test results on the treated ground for two locations, and significant variability can be observed between the two locations. The results of pressuremeter tests for pressuremeter modulus and limit pressure are shown in Figs. 21 and 22.

Loading tests were carried out on square steel plates $2.5 \mathrm{~m} \times 2.5 \mathrm{~m}$, and the load test results showed very different settlement behavior, with the test at Location 1 being much stiffer (approximately 8 times) than at Location 2. While the CPT tests indicated somewhat lower values at Location 2, neither these tests nor the pressuremeter tests showed such a large divergence in the soil stiffness. Backfigured average values of soil Young's modulus were 

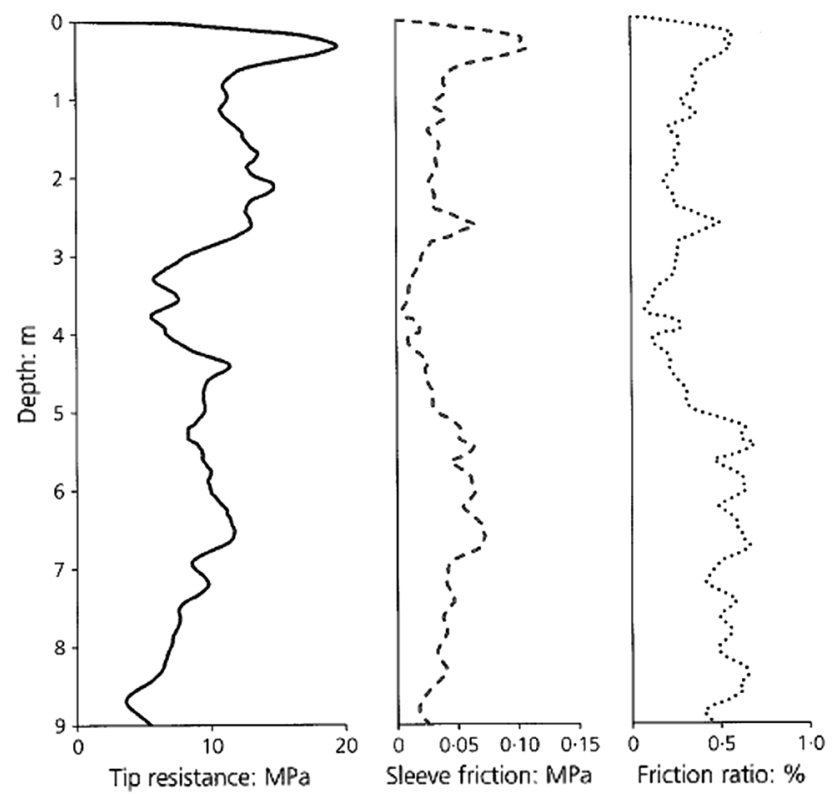

Fig. 19 CPT results for test location 1 [31]
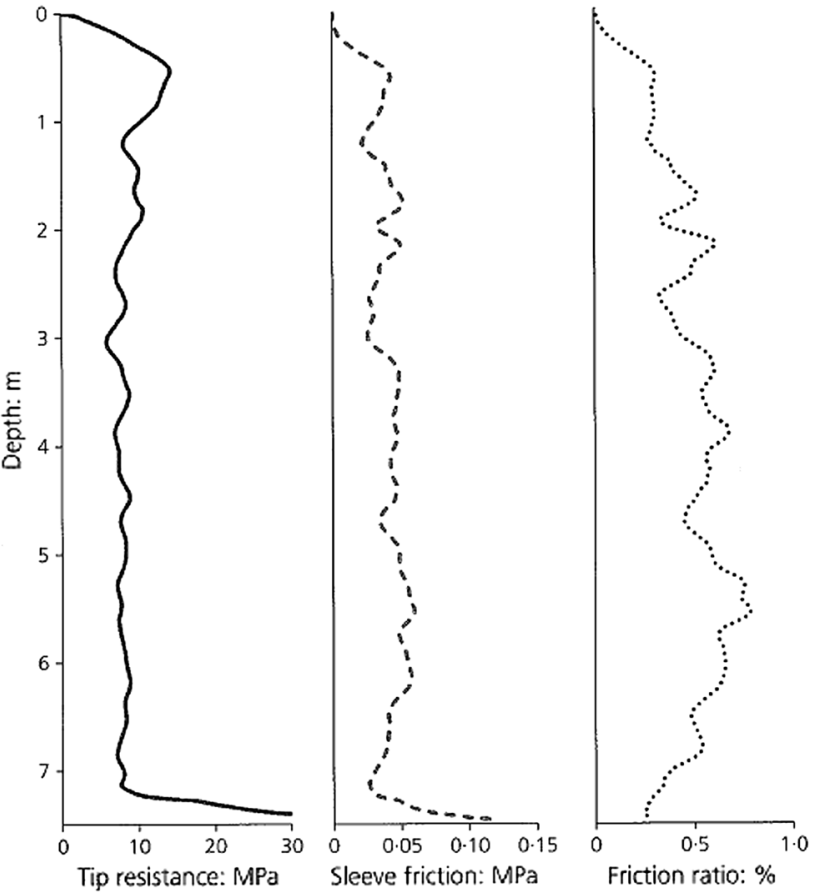

Fig. 20 CPT results for test location 2 [31]

about $32 \mathrm{MPa}$ for Location 1 and $4 \mathrm{MPa}$ for Location 2. Unfortunately, there appears to be no other published information that might assist in understanding the reasons for the divergence in stiffness at the sites, and also, the relatively low values of Young's modulus for the treated sands.
Pressuremeter modulus, $E: M P a$

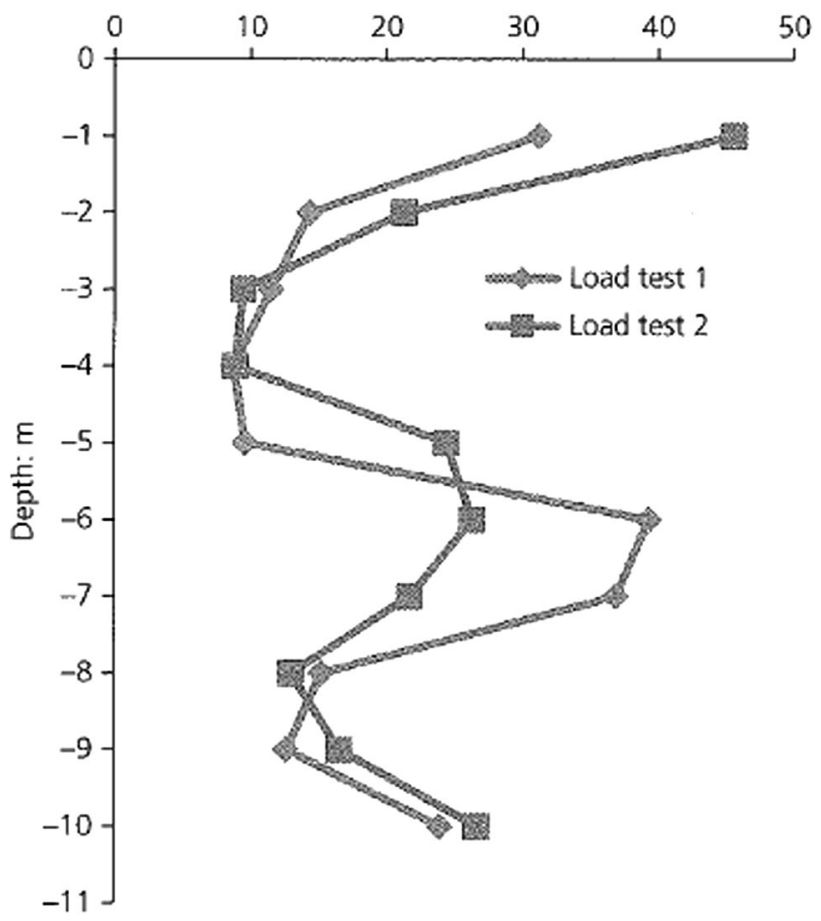

Fig. 21 Modulus values from pressuremeter tests [31]

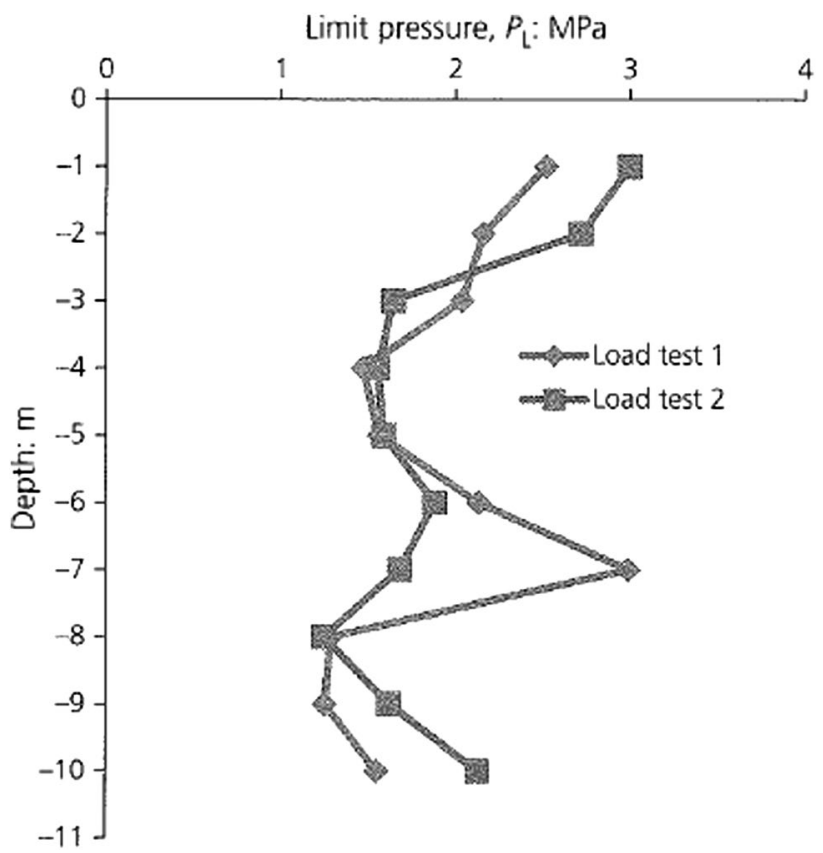

Fig. 22 Limit pressure values from pressure meter tests [31] 


\section{Conclusions}

From the foregoing descriptions of geology and geotechnical behaviour, it is possible to identify a number of factors which are present in Middle Eastern countries and which may be significant in designing foundations, especially for high-rise buildings. Among these factors are the following:

- Very weak rock with variable cementation. If subjected to high stresses and the cementation breaks down, these rocks may become very compressible and result in troublesome long-term settlements.

- Interbedded layers with variable properties, or deposits containing gypsum and so may be highly heterogeneous. In such cases, relatively small variations in foundation toe level may lead to considerable differences in pile performance characteristics.

- Deposits which are loose in their natural state, and rich in carbonates. They may be susceptible to degradation during cyclic loading.

- Limestone deposits with possible karstic features. The end bearing capacity of foundations in such conditions may be very small or absent, and there is also a risk that the ground support conditions may deteriorate with time if a solution cavity is formed.

- Ground conditions that do not necessarily improve with depth, at least within the feasible foundation depths. The conditions in Doha, Qatar, are an example of this phenomenon. In such cases, it may not be feasible or economical to achieve design objectives by increasing the length of the piles, and alternative strategies then need to be explored.

It is critical that such factors be identified during the ground investigation phase, and that appropriate in situ, laboratory and field testing be undertaken to assess the extent to which such factors, if present, may influence the foundation performance.

Another issue that may be important for foundation performance relates to the chemically aggressive ground conditions that often prevail, and that may cause accelerated deterioration of foundation materials such as steel and concrete. Fookes et al. [11] describe some of the possible consequences of such deterioration and point out that, without adequate care being taken in design and during construction, reinforced concrete in coastal areas of the Middle East may have only half the life expectancy of the same concrete in more temperate conditions.

Open Access This article is distributed under the terms of the Creative Commons Attribution 4.0 International License (http://creativeco mmons.org/licenses/by/4.0/), which permits unrestricted use, distribution, and reproduction in any medium, provided you give appropriate credit to the original author(s) and the source, provide a link to the Creative Commons license, and indicate if changes were made.

\section{References}

1. Abdullah W, Kamal H (2005) Characteristics of Desert Karst Terrain in Kuwait and the Eastern Coastline of the Arabian Peninsula. In: Beck BF (ed) Karst 2005. ASCE, Reston

2. Akili W (2002) Pile driving in coral deposits: a case study along the Red Sea. In: Proceedings of the international deep foundations congress, Orlando, FL

3. Akili W (2004) Foundations over salt-encrusted flats (sabkha): profiles, properties and design guidelines. In: Proceedings of the 5 th international conference on case histories in geotechnical engineering, New York, NY, Paper No. 1.43, p 19

4. Akili W, Torrance JK (1981) The development and geotechnical problems of sabkha, with preliminary experiments on the static penetration resistance on cemented sands. Q J Eng Geol Lond 14:59-73

5. Al-Rawas AA, Qarnaruddin M (1998) A case study on expansive soils and rocks of Al-Khod in Northern Oman. In: Proceedings of the 4th international conference case histories in geotechnical engineering, St. Louis, Mo., pp 219-223

6. Al-Refeai T, Al-Ghamdy D (1994) Geological and geotechnical aspects of Saudi Arabia. Geotech Geol Eng 12(4):253-276

7. Al-Sanad HA, Ismael N, Nayfeh AJ (1993) Geotechnical properties of dune sands in Kuwait. Eng Geol 34(1-2):45-52

8. Alrifai L (2007) Rock socket piles at Mall of the Emirates, Dubai. Geotech Eng 160(GE2):105-120

9. Droste HHJ (1997) Stratigraphy of the lower Paleozoic Haima supergroup of Oman. GeoArabia 2:419-492

10. Evans PL (1978) The Middle East-an outline of the geology and soil conditions in relation to construction problems. BRE CP13/78, Building Research Establishment, Watford, UK

11. Fookes PG, French WJ, Rice SMM (1985) The influence of ground and groundwater geochemistry on construction in the Middle East. Q J Eng Geol Hydrogeol 18:101-127

12. Hagenaar J, Van Seters A (1985) Ultimate axial bearing capacity of piles driven into coral rock and carbonate soils. In: Proceedings of the 12th International conference on soil mechanics and foundation engineering, San Francisco, USA, Paper, 41C15, pp $1599-1602$

13. Hossain D, Ali KM (1988) Shear strength and consolidation characteristics of Obhor Sabkha, Saudi Arabia. Q J Eng Geol Hydrogeol 21(4):347-359

14. Ismael NF (1989) Skin friction of driven piles in calcareous soils. J Geot Eng 115(1):136-139

15. Ismael NF (1990) Behaviour of laterally loaded bored piles in cemented sands. J Geot Eng 116(10):1678-1699

16. Ismael NF (1999) Properties and behaviour of cemented sand deposits in Kuwait. Soild Found 39(4):47-57

17. Ismael NF (1999) Analysis of load tests on piles driven through calcareous desert sands. J Geot Geoenviron Eng 125(10):905-908

18. Ismael NF (2001) Axial load tests on bored piles and pile groups in cemented sands. J Geotech Geoenviron Eng 127(9):766-773

19. Ismael NF, Jeragh AM, Mollah MA, Al-Khalidi O (1986) A study of the properties of surface soils in Kuwait. Geotech Eng 11:67-87

20. Ismael NF, Al-Sanad HA (1986) Uplift capacity of bored piles in calcareous soils. J Geotech Eng 112(10):928-940

21. Ismael NF, Mollah MA (1998) Leaching effects on properties of cemented sands in Kuwait. J Geotech Geoenviron Eng 124(10):997-1004

22. James AN, Little AL (1994) Geotechnical aspects of sabkha at Jubail, Saudi Arabia. Q J Eng Geol Hydrogeol 27(2):83-121

23. Kent PE (1978) Middle East— the geological background. Q J Eng Geol Hydrogeol 11:1-7 
24. Loosveld RJH, Bell A, Terken JJM (1996) The tectonic evolution of Oman. GeoArabia 1:28-51

25. Oweis I, Bowman J (1981) Geotechnical considerations for construction in Saudi Arabia. J Geotech Geoenviron Eng 108:319-327

26. Pollastro RM (1999) Ghana Salt Basin province and Fahud Salt Basin province, Oman-Geological Overview and total petroleum systems. U.S. Geol. Survey Open-File Report 99-50-D, U.S $>$ Department of the Interior

27. Poulos HG (2010) High-rise building foundations - a limit state design approach. The art of foundation engineering practice, ASCE, Geotechnical Special Publication No. 198, pp 501-516

28. Poulos HG, Davids AJ (2005) Foundation design for the Emirates Twin Towers, Dubai. Can Geotech J 42(3):716-730
29. Robertson AHF, Searle MP, Ries AC (eds) (1990) The geology and tectonics of the Oman region. Geological Society Special Publication No. 49. Geological Society, London, p 845

30. Saleh A, Al-Ruwaih F, Al-Reda A, Gunatilaka AS (1999) A reconnaissance study of a clastic coastal sabkha in Northern Kuwait, Arabian Gulf. J Arid Environ 43:1-19

31. Tarawneh B, Nusairat J, Hakam Y (2018) Load testing and settlement of shallow foundation on desert sands. Geotech Eng ICE Proc 171(GE1):52-63

32. Tonnisen JY, Den Haan EJ, Luger HJ, Dobie MJD (1989) "Pier Foundations of the Saudi Arabia - Bahrain Causeway". Proceedings of the 12th International Conference on Soil Mechanics and Foundation Engineering, Rio de Janeiro, Brazil, Paper 4/B/13, $1576-1578$ 